\title{
Adverse Events of Acupuncture: A Systematic Review of Case Reports
}

\author{
Shifen Xu, ${ }^{1,2}$ Lizhen Wang, ${ }^{2,3}$ Emily Cooper, ${ }^{2}$ Ming Zhang, ${ }^{4}$ Eric Manheimer, \\ Brian Berman, ${ }^{2}$ Xueyong Shen, ${ }^{3}$ and Lixing Lao ${ }^{2}$ \\ ${ }^{1}$ Acupuncture Department, Shanghai Municipal Hospital of Traditional Chinese Medicine, Shanghai 200071, China \\ ${ }^{2}$ Center for Integrative Medicine, School of Medicine, University of Maryland, East Hall, 520 W. Lombard Street, Baltimore, \\ MD 21201, USA \\ ${ }^{3}$ College of Acupuncture-Moxibustion and Tuina, Shanghai University of Traditional Chinese Medicine, Shanghai 201203, China \\ ${ }^{4}$ Department of Integrative Medicine, Shanghai Chest Hospital, Shanghai 200030, China
}

Correspondence should be addressed to Lixing Lao; llao@compmed.umm.edu

Received 23 December 2012; Accepted 8 February 2013

Academic Editor: Jaung-Geng Lin

Copyright (C) 2013 Shifen Xu et al. This is an open access article distributed under the Creative Commons Attribution License, which permits unrestricted use, distribution, and reproduction in any medium, provided the original work is properly cited.

Acupuncture, moxibustion, and cupping, important in traditional Eastern medicine, are increasingly used in the West. Their widening acceptance demands continual safety assessment. This review, a sequel to one our team published 10 years ago, is an evaluation of the frequency and severity of adverse events (AEs) reported for acupuncture, moxibustion, and cupping between 2000 and 2011. Relevant English-language reports in six databases were identified and assessed by two reviewers. During this 12 -year period, 117 reports of $308 \mathrm{AEs}$ from 25 countries and regions were associated with acupuncture (294 cases), moxibustion ( 4 cases), or cupping (10 cases). Country of occurrence, patient's sex and age, and outcome were extracted. Infections, mycobacterial, staphylococcal, and others, were the main complication of acupuncture. In the previous review, we found the main source of infection to be hepatitis, caused by reusable needles. In this review, we found the majority of infections to be bacterial, caused by skin contact at acupoint sites; we found no cases of hepatitis. Although the route of infection had changed, infections were still the major complication of acupuncture. Clearly, guidelines such as Clean Needle Technique must be followed in order to minimize acupuncture AEs.

\section{Introduction}

Traditional acupuncture, which is defined as needling insertion, moxibustion thermal stimulation, and cupping techniques at acupuncture points [1], has become popular in the United States and the rest of the world in recent decades. Data released by the National Institutes of Health (NIH) in 2008 reported that 3.1 million American adults and 150,000 children used acupuncture in 2007. Adult use of acupuncture increased by approximately a million people in the five years from 2002 to 2007 [2]. This increased use brings attention to the safety and quality of the modality.

A number of large surveys on the safety of acupuncture have been conducted, mainly in Europe. Most reported incidents have been fairly minor, and incidence rates were low.
For example, in a prospective survey of 34,000 treatments by traditional acupuncturists, MacPherson et al. [3] found no serious adverse events (AEs) and 43 minor ones, a rate of 1.3 per 1000 treatments. In another prospective survey, Melchart et al. [4] found 7.1\% minor AEs and 5 serious ones among 97,733 acupuncture patients. The authors of these studies concluded that serious AEs seem to be rare and that acupuncture is generally a safe intervention.

More than a decade since our last review [5], we have conducted this systematic follow-up review of case reports published between 2000 and 2011 on AEs and complications associated with acupuncture. Our purpose is to (1) estimate the trend of occurrences of the AEs associated with acupuncture over the past 11 years, (2) identify risk factors in acupuncture practice in order to minimize such events, and 


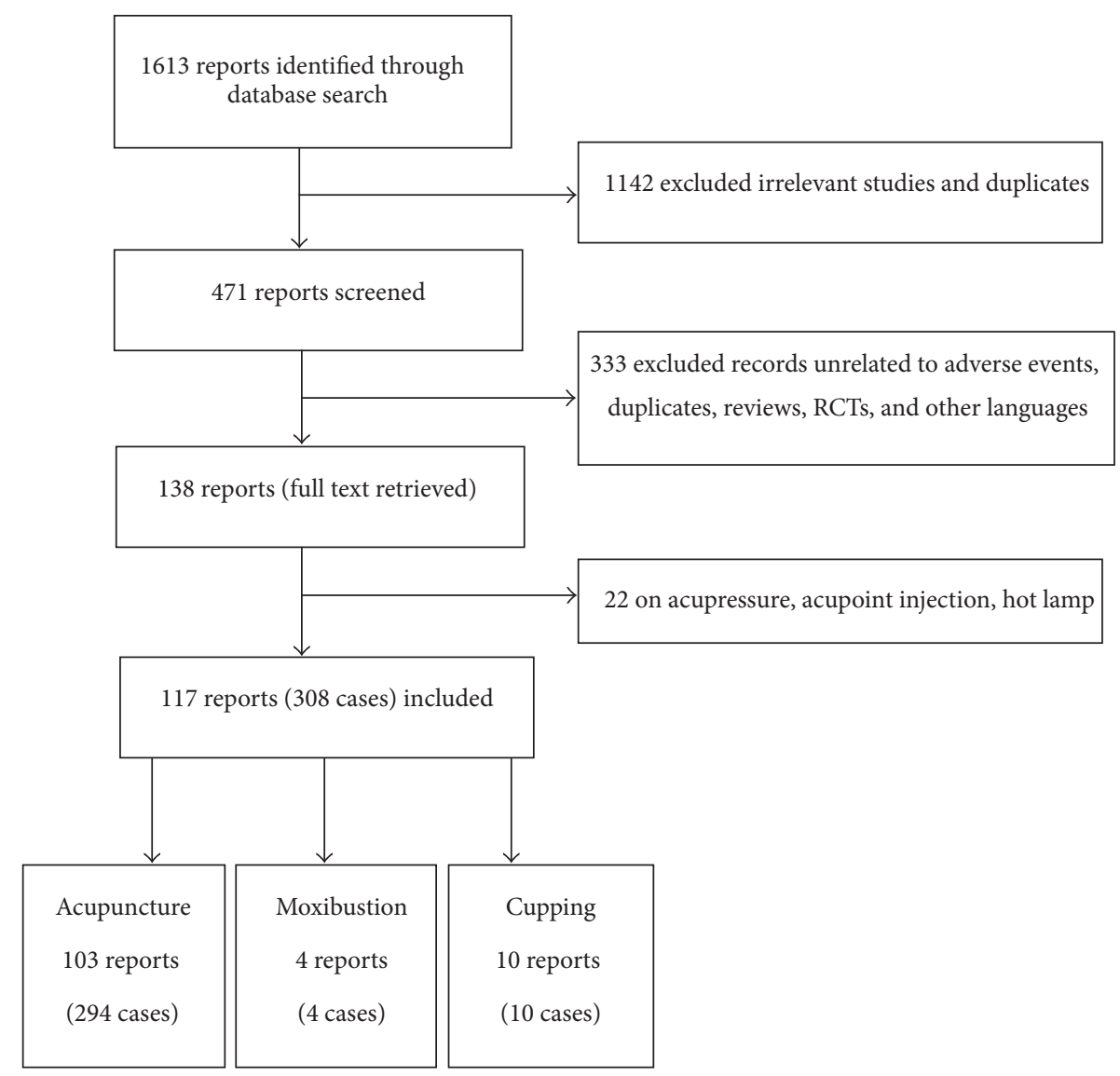

FIGURE 1: Flow chart of the screening process.

(3) recommend safe acupuncture practices based on these reported incidents in order to enhance professional standards of practice.

\section{Materials and Methods}

2.1. Search Strategy. We searched six databases in an attempt to locate any and all existing English-language case reports on acupuncture AEs published between 2000 and 2011 in electronic form. PubMed, Medline, the Central Information System of Complementary Medicine (CISCOM), Excerpta Medica (EMBASE), Citations in Nursing and Allied Health Literature (CINAHL), and the Complementary and Alternative Medicine for Pain (CAMPAIN) were searched. Search terms were "acupuncture, acupuncture anesthesia, acupuncture analgesia, electroacupuncture, acupuncture points, auricular acupuncture, moxibustion, needling, and cupping." These terms were combined with "safe, safety, adverse event, adverse reaction, side effects, complications, and risk."

2.2. Inclusion and Exclusion Criteria. Only original case reports of complications or AEs of acupuncture, moxibustion, and cupping published from 2000 to 2011 were included in this review. Two authors independently screened the titles and abstracts of all papers found from the initial search. Disagreements between the two authors were resolved through discussion.

We excluded multiple inclusions and analyses of the same $\mathrm{AE}$ as well as irrelevant studies. An irrelevant study was defined as a non-case report, such as a review, commentary, or clinical trial.

AEs reporting infection, internal organ or tissue injury, and other severe consequences are categorized as "complications," defined as an added difficulty; a complex state; a disease or accident superimposed upon another without being specifically related. Peripheral or secondary effects such as syncope, nausea, or immune reactions are classified as "adverse reactions" [5].

2.3. Data Extraction. A total of 1613 papers were found; 117 were relevant (Figure 1). When provided, we extracted author, year of publication, country of occurrence, number of patients affected, disease originally treated, preexisting conditions that might have contributed to the AE, the needling site, the reported $\mathrm{AE}$ and its outcome, the practitioner's training, and the patient's status at followup. The majority of the reports did not give the date of the AEs. The data were extracted by two independent coauthors, double checked to ensure matching, and organized by whether the AEs were (1) complications or (2) adverse reactions. 
TABLE 1: Adverse events associated with acupuncture, moxibustion, and cupping (2000-2011).

\begin{tabular}{lc}
\hline Adverse events & Number of cases \\
\hline Acupuncture & \\
Complications & 284 \\
$\quad$ Infections & 239 \\
$\quad$ Isolated incidents & 48 \\
$\quad$ Outbreaks & 191 \\
Internal organ or tissue injury & 38 \\
$\quad$ Pneumothorax & 13 \\
$\quad$ Central nerve system & 9 \\
$\quad$ Peripheral nerves & 4 \\
$\quad$ Heart & 5 \\
Other injuries & 7 \\
Other complications & 7 \\
Adverse reactions & 10 \\
Moxibustion & 4 \\
Cupping & 10 \\
\hline Total & 308 \\
\hline
\end{tabular}

\section{Results}

For the years 2000-2011, a total of 117 reports containing 308 AEs associated with acupuncture (294 cases), moxibustion ( 4 cases), and cupping (10 cases) were identified from 25 countries and regions (Table 1).

3.1. Acupuncture Complications: Infections. A total of 239 reported cases were infections associated with acupuncture. These include 48 individual isolated cases reported in 45 papers (Table 2) and 191 cases reported in five outbreaks (Table 3 ). Incidents were reported in 17 countries and regions. Korea reported 162 cases, Canada 33, Hong Kong 7, Australia 8, Japan 5, Taiwan 5, UK 4, USA 6, Spain 1, Ireland 1, France 1, Malaysia 1, Croatia 1, Scotland 1, Venezuela 1, Brazil 1, and Thailand 1 . Most of the papers did not report the practitioner's training, but 4 cases were treated by individuals with no medical training or license $[6,7]$. One patient with a knee infection died due to renal failure [8]. All other cases recovered after the infection was treated.

3.2. Mycobacterium Infection. Of the 239 cases of infection, 193 (80.75\%; 153 from Korea, 32 from Canada, 5 from Hong Kong, 1 from Venezuela, 1 from Brazil, and 1 from Spain) were associated with mycobacterium.

In 2006, Song et al. reported an outbreak of 40 cases of infection in an Oriental medicine clinic in Republic of Korea. Although disposable acupuncture needles were used, the patients developed skin lesions at two or more sites on the body; infections were confirmed by laboratory culture, clinical signs, and histopathology. All patients recovered after active treatment with antibiotics. Reportedly, these patients received hot-pack therapy and gel massage after acupuncture treatment. No further cases were found in that clinic after equipment sterilization, and regular towel changes were instituted. The authors of the report concluded that the outbreak of infection was due to improper sterilization of equipment applied to the skin after withdrawal of acupuncture needles [52].

In 2006, Tang et al. reported an outbreak of acupunctureassociated bacterial infection in Canada. Between April and December 2002, thirty-two patients developed cutaneous mycobacteriosis after visiting an acupuncture practice in Toronto. Interviews with the patients and acupuncturist revealed that needles were reused and kept in a container of glutaraldehyde disinfectant prior to insertion. The solution was no longer available at the time of the investigation but was probably improperly diluted with tap water [51].

In 2009, Koh et al. reported an outbreak of 109 cases of skin and soft tissue infection in an acupuncture clinic in Republic of Korea. Most patients had at least one skin lesion. Investigators determined that disposable acupuncture needles were used and were unlikely to be the source of infection. Infected patients were all treated by a physical therapy called "interferential current therapy" or "low-frequency therapy." The authors found that the diluted disinfectant used to sanitize the therapeutic equipment had been prepared several months earlier and was contaminated with Mycobacterium abscessus, the likely source of the outbreak [54].

Woo et al. reported four cases of infection by alcoholresistant mycobacterium, discovered over a two-year period, in patients with skin lesions who were receiving acupuncture treatment in Hong Kong (Table 3). The patients had clinical and/or radiological lesions at acupuncture points. The acupuncturists' training and whether disposable acupuncture needles were used were not reported. The authors recommended that proper infection control guidelines for acupuncture should be mandatory and strictly implemented [50].

3.3. Staphylococcus Infection. Nineteen cases from 14 case reports concern staphylococcus infections associated with acupuncture $[14,15,17,21,25,27,28,30,33,38,39,46,47,53]$. Of these, nine patients were infected by methicillin-resistant Staphylococcus aureus (MRSA): six from Australia [53], one from Korea [33], one from Taiwan [47], and one from Hong Kong [38].

In the Australian case, Murray et al. reported a 2008 outbreak of eight cases of invasive MRSA, six of them associated with acupuncture (Table 3 ). After extensive investigation, the authors concluded that the outbreak most likely resulted from a breakdown in sterile technique during the acupuncture procedure and that the MRSA was probably transmitted from the medical practitioner to the patients. At two time points fifteen months apart, that practitioner had been positively colonized with the MRSA strain that caused the infection [53].

3.4. Other Infections. Other infections (31 cases) include septic arthritis $[10,23,31,39]$, necrotizing fasciitis [26, 45, 49], pneumoretroperitoneum [34, 36], facial erysipelas [20], 


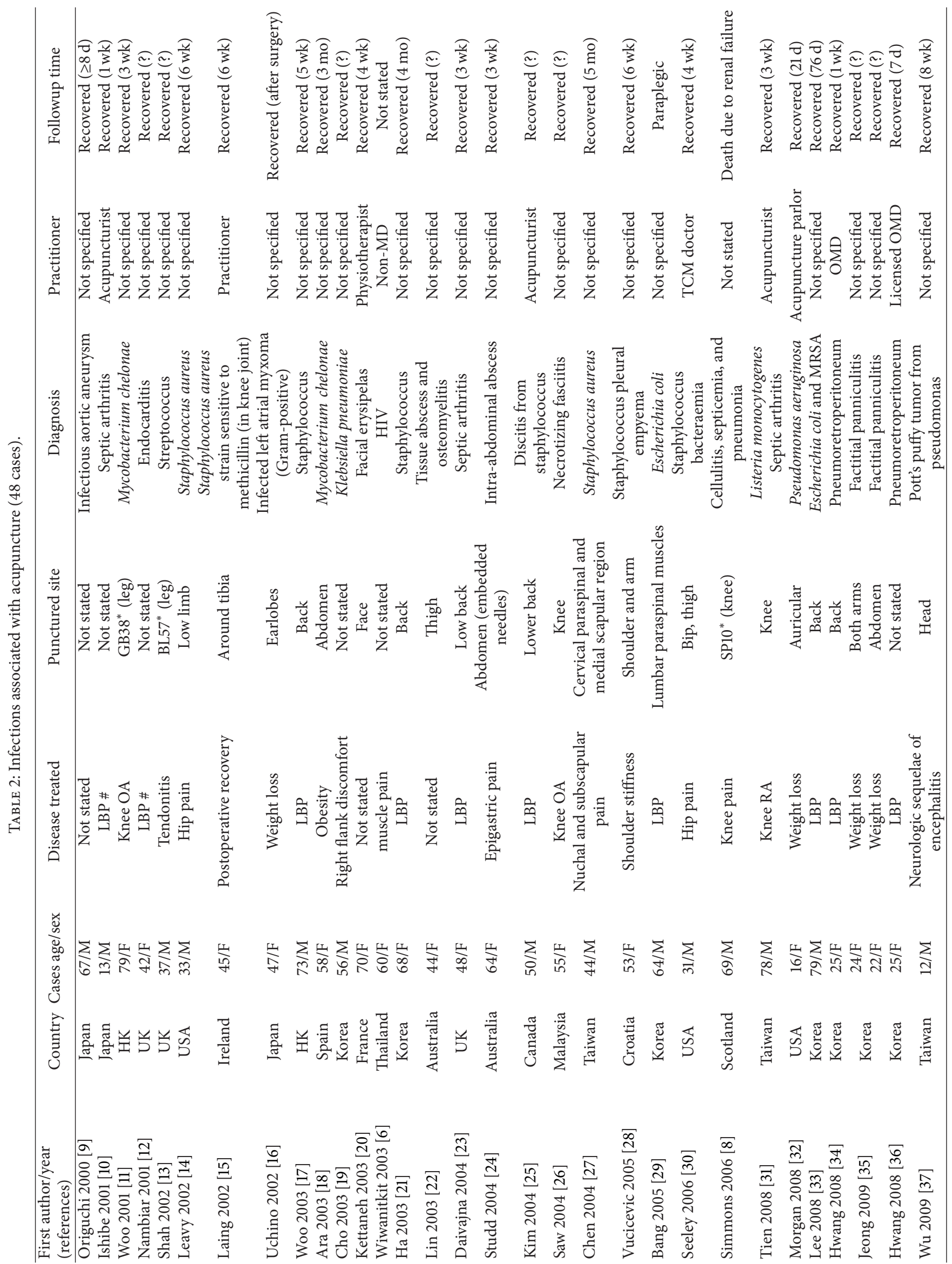




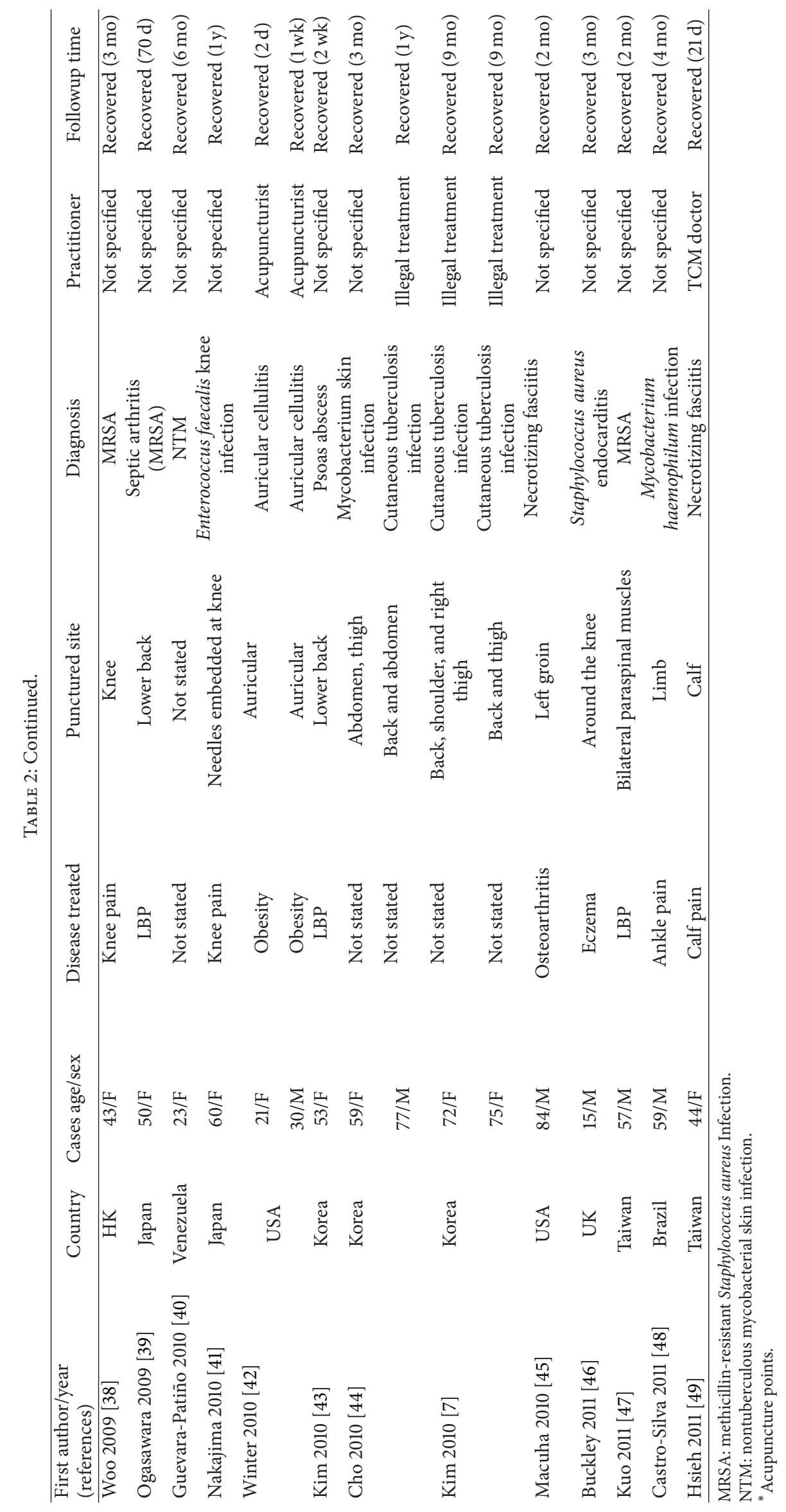


TABLE 3: Infectious outbreaks associated with acupuncture (191 cases).

\begin{tabular}{lccccc}
\hline First author/year (references) & Country & Cases & Diagnosis & Practitioner & Followup time \\
\hline Woo 2002 [50] & HK & 4 & Alcohol-resistant mycobacteria & Not specified & Recovered \\
Tang 2006 [51] & Canada & 32 & Mycobacteriosis & Acupuncturist & Recovered \\
Song 2006 [52] & Korea & 40 & Mycobacteriosis & Oriental medical clinic & Recovered \\
Murray 2008 [53] & Australia & 6 & MRSA & Acupuncturist & Recovered \\
Koh 2010 [54] & Korea & 109 & Mycobacteriosis & Acupuncturist & Recovered \\
\hline
\end{tabular}

TAble 4: Pneumothoraxes associated with acupuncture (13 cases).

\begin{tabular}{|c|c|c|c|c|c|c|}
\hline $\begin{array}{l}\text { First author /year } \\
\text { (reference) }\end{array}$ & Country & Cases age/sex & Disease treated & Punctured site & Practitioner & Followup \\
\hline Kao [58] & Taiwan & $28 / \mathrm{F}$ & Back pain & Thoracic spine bilaterally & Not specified & Recovered (2d) \\
\hline Leung 2002 [59] & HK & $70 / \mathrm{F}$ & Asthma & Thoracic spine bilaterally & Acupuncturist & Not stated \\
\hline Iwadate 2003 [60] & Japan & $72 / \mathrm{F}$ & Stiff neck & Thoracic cavity & $\begin{array}{l}\text { Acupuncture } \\
\text { clinic }\end{array}$ & Death \\
\hline Peuker 2004 [61] & Germany & $38 / \mathrm{F}$ & Breathing problem & $\begin{array}{l}\text { Points at chest and upper } \\
\text { back (LU1 and BL13) }\end{array}$ & $\begin{array}{c}\text { Medical } \\
\text { acupuncturist }\end{array}$ & $\begin{array}{l}\text { Recovered } \\
\quad(1 \mathrm{wk})\end{array}$ \\
\hline Saifeldeen 2004 [62] & UK & $31 / \mathrm{M}$ & Shoulder pain & Right scapular region & Not specified & $\begin{array}{l}\text { Recovered } \\
\quad(1 \mathrm{wk})\end{array}$ \\
\hline Lee 2005 [63] & $\mathrm{HK}$ & $36 / \mathrm{F}$ & Back pain & Upper back & $\begin{array}{l}\text { Registered TCM } \\
\text { practitioner }\end{array}$ & Recovered (5d) \\
\hline Chauffe 2006 [64] & USA & $27 / \mathrm{M}$ & Upper back pain & Upper back (T2-8 levels) & Not specified & Recovered (2d) \\
\hline Su 2007 [65] & Singapore & $52 / \mathrm{F}$ & Chronic bronchitis & Upper back (T3) & Not specified & Recovered (2d) \\
\hline $\begin{array}{l}\text { Von Riedenauer } 2007 \\
{[66]}\end{array}$ & USA & $25 / \mathrm{M}$ & Shoulder pain & $\begin{array}{c}\text { Migration of embedded } \\
\text { needles }\end{array}$ & Not specified & $\begin{array}{l}\text { Recovered } \\
\quad(1 \mathrm{wk})\end{array}$ \\
\hline Juss 2008 [67] & UK & $50 / \mathrm{F}$ & Neck and back pain & $\begin{array}{c}\text { Acupoints at upper back } \\
\text { (BL13, BL14, BL15, and } \\
\text { BL16) }\end{array}$ & Physiotherapist & Recovered (2 d) \\
\hline Richter 2008 [68] & New Zealand & $35 / \mathrm{F}$ & Back pain & Back region & Physiotherapist & Recovered (10 d) \\
\hline Kennedy 2010 [69] & USA & $54 / \mathrm{F}$ & Musculoskeletal pain & Left side chest & Not specified & Recovered (?) \\
\hline Inayama 2011 [70] & Japan & $37 / \mathrm{F}$ & Not stated & Neck and upper back & Acupuncturist & Recovered (12 d) \\
\hline
\end{tabular}

HIV [6], Listeria monocytogenes-caused arthritis [31], and infections by Enterococcus faecalis [41] and Pseudomonas [32, 37]. Although most of the reports did not state possible cause of the infections, reusable needles were used in a few cases.

3.5. Acupuncture Complications: Organ and Tissue Injuries. Of 38 cases of organ or tissue injuries, 13 were pneumothoraxes (Table 4); 9 were central nerve system injuries (Table 5); 4 were peripheral nerve injuries (Table 6); 5 were heart injuries (Table 7); 7 were other organ and tissue injuries (Table 8). The cases were distributed among ten countries: 10 from South Korea, 6 from the USA, 6 from Taiwan, 5 from Japan, 3 from the UK, 2 from Germany, 2 from Hong Kong, 1 from Austria, 1 from Iran, 1 from Singapore, and 1 from New Zealand. Although most papers did not report the training background of the practitioner, 3 cases were reportedly treated by individuals with no medical training or license [5557].

3.6. Pneumothorax (Table 4). Of 13 cases of pneumothorax [58-70] associated with acupuncture, the USA reported 3, the UK 2, Hong Kong 2, Japan 2, Singapore 1, Germany 1, Taiwan 1, and New Zealand 1. Most of these were reported by emergency room physicians. The major patient complaints were dyspnea and chest pain; pneumothorax was confirmed by X-ray. All but one of the 13 patients recovered. A 72-yearold woman died 90 minutes after an acupuncture treatment; autopsy confirmed that the cause was needle penetration of the thoracic cavity [60].

3.7. Central Nervous System Injury (Table 5). There were nine cases of central nervous system injury, including five spinal cord injuries $[55,73-75,77]$ and four of brain injury $[56,71$, 72, 76].

Two of the spinal injuries were caused by migrating broken needles $[55,75]$; the others were probably the result of needling too deeply. All patients recovered after treatment.

The brain injuries were an acute intracranial hemorrhage [71], an injury to the medulla oblongata [72], a subarachnoid hemorrhage [76], and an intracranial hemorrhage with cerebellar infarction [56]. Three were due to needle insertion; the medulla injury was caused by a broken needle. Three 
TABLE 5: Central nervous system injuries associated with acupuncture (9 cases).

\begin{tabular}{|c|c|c|c|c|c|c|c|c|}
\hline $\begin{array}{l}\text { First author /year } \\
\text { (reference) }\end{array}$ & Country & Cases age/sex & $\begin{array}{l}\text { Disease } \\
\text { treated }\end{array}$ & $\begin{array}{c}\text { Punctured } \\
\text { site }\end{array}$ & Complication & $\begin{array}{l}\text { Onset after } \\
\text { acupuncture }\end{array}$ & Practitioner & Followup \\
\hline Choo $2000[71]$ & USA & $44 / \mathrm{M}$ & Neck pain & GV16 (neck) & $\begin{array}{l}\text { Acute intracranial } \\
\text { hemorrhage }\end{array}$ & Immediately & Not specified & $\begin{array}{l}\text { Recovered } \\
\quad(10 \mathrm{~d})\end{array}$ \\
\hline Hama 2004 [72] & Japan & $70 / \mathrm{M}$ & Not stated & $\begin{array}{l}\text { Not stated } \\
\text { (broken } \\
\text { needle) }\end{array}$ & $\begin{array}{l}\text { Medulla oblongata } \\
\text { injury, left facial } \\
\text { paresthesia }\end{array}$ & $3 \mathrm{wk}$ & Not specified & Recovered (1y) \\
\hline Eftekhar 2005 [73] & Iran & $74 / \mathrm{M}$ & LBP & $\begin{array}{l}\text { Lumbar } \\
\text { region }\end{array}$ & Epidural hematoma & Shortly & Not specified & $\begin{array}{c}\text { Recovered } \\
\text { (after surgery) }\end{array}$ \\
\hline Chen 2006 [74] & Taiwan & $30 / \mathrm{M}$ & Back pain & Upper back & Epidural haematoma & $1 \mathrm{~h}$ & Acupuncturist & $\begin{array}{c}\text { Recovered } \\
\text { (after surgery) }\end{array}$ \\
\hline Ulloth 2007 [75] & USA & $52 / \mathrm{M}$ & LBP & $\begin{array}{l}\text { L1, L2, and L3 } \\
\text { Vertebrae } \\
\text { (embedded } \\
\text { needles) }\end{array}$ & $\begin{array}{l}\text { Cerebrospinal fluid } \\
\text { fistula }\end{array}$ & $14 \mathrm{mo}$ & Acupuncturist & $\begin{array}{c}\text { Recovered } \\
\text { (after surgery) }\end{array}$ \\
\hline Liou 2007 [55] & Taiwan & $29 / \mathrm{M}$ & $\begin{array}{l}\text { Stiffness of } \\
\text { neck }\end{array}$ & $\begin{array}{c}\text { Epidural } \\
\text { space at C2 } \\
\text { level (a } \\
\text { broken } \\
\text { needle) }\end{array}$ & Spinal Cord Injury & $3 y$ & $\begin{array}{l}\text { "Nonmedical } \\
\text { practitioner" }\end{array}$ & $\begin{array}{c}\text { Recovered } \\
\text { (after surgery) }\end{array}$ \\
\hline $\begin{array}{l}\text { Tsukazaki } 2008 \\
\text { [76] }\end{array}$ & Japan & $32 / \mathrm{F}$ & Not stated & GV16 (neck) & $\begin{array}{l}\text { Subarachnoid } \\
\text { hemorrhage }\end{array}$ & $1 \mathrm{~d}$ & $\begin{array}{c}\text { Oriental } \\
\text { medicine clinic }\end{array}$ & Not stated \\
\hline Lee 2011 [77] & Korea & $58 / \mathrm{F}$ & $\begin{array}{l}\text { Quadri- } \\
\text { paresis } \\
\text { neck pain }\end{array}$ & Neck & $\begin{array}{l}\text { Cervical epidural } \\
\text { hematoma }\end{array}$ & $1 \mathrm{~h}$ & $\begin{array}{l}\text { Family } \\
\text { physician }\end{array}$ & $\begin{array}{l}\text { Recovered } \\
(8 \mathrm{wk})\end{array}$ \\
\hline Heo 2011 [56] & Korea & $65 / \mathrm{M}$ & Not stated & $\begin{array}{l}\text { Posterior } \\
\text { neck }\end{array}$ & $\begin{array}{c}\text { Intracranial } \\
\text { hemorrhage and } \\
\text { cerebellar infarction }\end{array}$ & $3 \mathrm{~d}$ & $\begin{array}{l}\text { Unauthorized } \\
\text { acupuncturist }\end{array}$ & $\begin{array}{l}\text { Recovered } \\
\quad(1 \mathrm{mo})\end{array}$ \\
\hline
\end{tabular}

TABLE 6: Peripheral nerve injuries associated with acupuncture (4 cases).

\begin{tabular}{|c|c|c|c|c|c|c|c|c|}
\hline $\begin{array}{l}\text { First author /year } \\
\text { (reference) }\end{array}$ & Country & $\begin{array}{c}\text { Cases } \\
\text { age/sex }\end{array}$ & $\begin{array}{l}\text { Disease } \\
\text { treated }\end{array}$ & $\begin{array}{c}\text { Punctured } \\
\text { site }\end{array}$ & Complication & $\begin{array}{c}\text { Onset after } \\
\text { acupuncture }\end{array}$ & Practitioner & Followup \\
\hline Sato 2003 [78] & Japan & $62 / \mathrm{F}$ & Sciatica & $\begin{array}{c}\text { Anterior of } \\
\text { the leg }\end{array}$ & $\begin{array}{l}\text { Peroneal nerve } \\
\text { palsy }\end{array}$ & $1 \mathrm{~d}$ & Not specified & $\begin{array}{l}\text { Recovered } \\
\quad(4 \mathrm{mo})\end{array}$ \\
\hline Patrick 2005 [79] & USA & $63 / \mathrm{F}$ & LBP & Low back & $\begin{array}{l}\text { Injury of the L5 } \\
\text { nerve root }\end{array}$ & $28 \mathrm{y}$ & Not specified & $\begin{array}{c}\text { Recovered } \\
\text { (after surgery) }\end{array}$ \\
\hline Rosted 2007 [80] & UK & $47 / \mathrm{M}$ & TMD & $\begin{array}{l}\text { ST6, ST7 } \\
\text { (face) }\end{array}$ & Bell's Palsy & $1 \mathrm{~d}$ & Not specified & $\begin{array}{c}\text { Recovered } \\
\text { (2wk) }\end{array}$ \\
\hline Lee 2008 [81] & Korea & $47 / \mathrm{M}$ & $\begin{array}{l}\text { Abdominal } \\
\text { discomfort }\end{array}$ & $\begin{array}{l}\text { PC5 \& PC6 } \\
\text { (forearm) }\end{array}$ & $\begin{array}{l}\text { Median nerve } \\
\text { neuropathy }\end{array}$ & Shortly & $\begin{array}{l}\text { Oriental medicine } \\
\text { practitioner }\end{array}$ & Recovered (1y) \\
\hline
\end{tabular}

TABLE 7: Heart injuries associated with acupuncture (5 cases).

\begin{tabular}{|c|c|c|c|c|c|c|c|c|}
\hline $\begin{array}{l}\text { First author /year } \\
\text { (reference) }\end{array}$ & Country & $\begin{array}{c}\text { Cases } \\
\text { age/sex }\end{array}$ & $\begin{array}{l}\text { Disease } \\
\text { treated }\end{array}$ & Punctured site & Complication & $\begin{array}{c}\text { Onset after } \\
\text { acupuncture }\end{array}$ & Practitioner & Followup \\
\hline $\begin{array}{l}\text { Kirchgatterer } \\
2000[82]\end{array}$ & Austria & $83 / \mathrm{F}$ & Not stated & Sternum & $\begin{array}{c}\text { Cardiac } \\
\text { tamponade }\end{array}$ & $20 \mathrm{~min}$ & $\begin{array}{c}\text { Experienced } \\
\text { acupuncturist }\end{array}$ & $\begin{array}{c}\text { Recovered } \\
(2 \mathrm{wk})\end{array}$ \\
\hline Park 2004 [83] & Korea & $49 / \mathrm{F}$ & $\begin{array}{l}\text { Shoulder } \\
\text { pain }\end{array}$ & $\begin{array}{l}\text { Shoulders and } \\
\text { upper back }\end{array}$ & $\begin{array}{c}\text { Cardiac } \\
\text { tamponade }\end{array}$ & $2 \mathrm{~h}$ & Not specified & $\begin{array}{c}\text { Recovered } \\
\text { (after surgery) }\end{array}$ \\
\hline Kim 2006 [84] & Korea & $70 / \mathrm{M}$ & $\begin{array}{l}\text { Chronic } \\
\text { lung disease }\end{array}$ & $\begin{array}{l}\text { Neck, chest, and } \\
\text { abdomen } \\
\text { (embed needles) }\end{array}$ & $\begin{array}{l}\text { Right ventricular } \\
\text { embolism }\end{array}$ & $1 y$ & Not specified & Not stated \\
\hline Song 2010 [85] & Korea & $69 / \mathrm{F}$ & Pain & $\begin{array}{l}\text { Shoulders and } \\
\text { neck (implanted } \\
\text { needles) }\end{array}$ & $\begin{array}{l}\text { Myocardium } \\
\text { injury }\end{array}$ & $10 y$ & $\begin{array}{l}\text { Traditional } \\
\text { medicine } \\
\text { practitioner }\end{array}$ & Unknown \\
\hline Kim 2011 [57] & Korea & $54 / f$ & $\begin{array}{l}\text { Myalgia and } \\
\text { dyspepsia }\end{array}$ & Chest, abdomen & Hemopericardium & $30 \mathrm{~min}$ & $\begin{array}{l}\text { Unauthorized } \\
\text { acupuncturist }\end{array}$ & Recovered (6d) \\
\hline
\end{tabular}


patients recovered after treatment; outcome was not given for the fourth (Table 5).

3.8. Peripheral Nerve Injury (Table 6). Four reported cases of peripheral nerve injury were associated with acupuncture treatment [78-81], one each in Japan, Korea, the USA, and the UK. The injured nerves were the peroneal nerve via acupuncture point GB34 the median nerve via PC5 and PC6, the facial nerve via ST7 and ST8, and the L5 nerve root via a broken needle in the lumbar region. All patients recovered.

3.9. Heart Injury (Table 7). Five cases of heart injury include two of cardiac tamponade $[82,83]$, one of the hemopericardium [57], one ventricular embolism [84], and one myocardial injury [85]. Of these, two were due to the migration of embedded needles $[83,84]$ and two were due to needle insertion $[57,82]$. Two were caused by an acupuncturist or TCM practitioner, and one by an "unauthorized acupuncturist" [57]. The status of two practitioners was unreported. Three patients recovered; outcome was not reported in the other two cases.

3.10. Other Organ and Tissue Injuries (Table 8). Seven cases of other organ and tissue injuries were found: a pseudoaneurysm of the abdominal aorta [86], a pseudoaneurysm of the popliteal artery [87], acute traumatic pancreatitis [88], an aortoduodenal fistula causing direct communication between the aorta and the GI tract [89], a rectus sheath hematoma [90], ear hematomas [91], and a popliteal arteriovenous fistula [92]. The patient with acute traumatic pancreatitis had been treated with $13 \mathrm{~cm}$ needles placed at three sites on the anterior abdominal wall. Abdominal computed tomography revealed small multiple gold acupuncture needles on the anterior abdominal wall and back muscles. The patient's condition quickly improved with fasting and intravenous fluids [88]. One patient died [89].

3.11. Other Complications of Acupuncture. Seven other complications associated with acupuncture were reported (Table 9): bilateral hand edema [93], epithelioid granuloma at needling sites [94], pseudolymphoma [95], localized argyria [96], pustules [97], pancytopenia [98], and scars at needling sites [99]. The localized argyria and pancytopenia were caused by needles embedded 20 and 17 years earlier, respectively $[96,98]$, in a type of Japanese acupuncture reported in our previous review [5]. The epithelioid granulomas were caused by silicone coating on the needles [94]. The scars were due to a hot needle technique in which the needles were heated in fire before insertion [99].

3.12. Adverse Reactions Associated with Acupuncture. Ten cases of adverse reactions from acupuncture were found (Table 10): three of syncope from two reports [100, 101]; two of galactorrhoea (spontaneous milk flow) $[102,103]$; one of bilateral nystagmus [104]; one of pyoderma gangrenosum due to immune reaction, in which the tissue became necrotic and deep ulcers formed [105]; one of hepatotoxicity [106]; one of eruptive lichen planus [107]; one of spontaneous needle migration [108]. These unusual cases are uncommonly seen in regular acupuncture practice. The case report authors postulated that these AEs were likely caused by a rare physiological reaction to the acupuncture needle. For example, the case report of spontaneous needle movement involved the acupuncture needles having "spontaneously moved deeper as far as the hilt, travelling an extra depth of $5-10 \mathrm{~mm}$," which was observed repeatedly on the same patient. Although there was no resulting complicating in this case, the authors cautioned that this could have caused serious complications if the needles had been placed near a vital organ [108].

The syncope cases occurred immediately or several minutes after a first acupuncture treatment; the patients were sitting or semirecumbent during treatment $[100,101]$.

3.13. Complications Associated with Moxibustion. Four AEs associated with moxibustion were found (Table 11): bruising [109], burns and cellulitis [110], spinal epidural abscess [111], and large superficial basal cell carcinoma [112]. Of these, two were self-administered $[111,112]$. An "untrained individual" performed the third [110]; there was no information on the fourth [109].

3.14. AEs Associated with Cupping. Ten AEs associated with cupping were found (Table 12): four from Turkey, three from Korea, two from Taiwan, and one from the UK. Most were minor: keloid scarring [113], burns [114, 115], and bullae $[116,117]$. Several were serious: acquired hemophilia A [118], stroke 14 hours after cupping on the back and neck [119], factitious panniculitis [120], reversible cardiac hypertrophy [121], and iron deficiency anemia [122]. These last two cases involved cupping with bleeding $[121,122]$. In six cases, there was no information on practitioner training; in the other four, treatment was self-administered.

\section{Discussion}

Our primary objective in reviewing case reports of AEs associated with acupuncture has been to identify individual cases and outbreaks of AEs and to analyze their possible causes, in order to minimize future acupuncture AEs and enhance safe practice within the profession. How do the objectives and results of this review fit in the context of other available literatures on the safety of acupuncture? Incidence rates for major AEs of acupuncture are best estimated from large prospective surveys of practitioners. Four recent surveys of acupuncture safety among regulated, qualified practitioners, two conducted in Germany $[4,123]$ and two in the United Kingdom [3, 124], confirm that serious adverse events after acupuncture are uncommon. Indeed, of these surveys, covering more than 3 million acupuncture treatments all together, there were no deaths or permanent disabilities, and all those with AEs fully recovered [125]. Thus, it can be concluded that acupuncture has a very low rate of AEs, when conducted among licensed, qualified practitioners in the West. Recent systematic reviews of RCTs of acupuncture [126-128], in which the acupuncture procedure is also 
TABLE 8: Other organ or tissue injuries associated with acupuncture (7 cases).

\begin{tabular}{|c|c|c|c|c|c|c|c|c|}
\hline $\begin{array}{l}\text { First author /year } \\
\text { (reference) }\end{array}$ & Country & $\begin{array}{c}\text { Cases } \\
\text { age/sex }\end{array}$ & $\begin{array}{l}\text { Disease } \\
\text { treated }\end{array}$ & Punctured site & Complication & $\begin{array}{c}\text { Onset after } \\
\text { acupuncture }\end{array}$ & Practitioner & Followup \\
\hline Kim 2002 [86] & Korea & $54 / \mathrm{M}$ & $\begin{array}{l}\text { Abdominal } \\
\text { pain }\end{array}$ & Back & $\begin{array}{l}\text { Pseudoaneurysm } \\
\text { of abdominal aorta }\end{array}$ & Immediately & OMD & $\begin{array}{l}\text { Recovered } \\
\quad(8 \mathrm{~d})\end{array}$ \\
\hline Kao 2002 [87] & Taiwan & $61 / F$ & Osteoarthritis & Knee & $\begin{array}{c}\text { Pseudoaneurysm } \\
\text { of the popliteal } \\
\text { artery }\end{array}$ & $6 \mathrm{mo}$ & Not specified & $\begin{array}{l}\text { Recovered } \\
\quad \text { (in } 1 \mathrm{y})\end{array}$ \\
\hline Uhm 2005 [88] & Korea & $42 / \mathrm{F}$ & Dyspepsia & Abdomen & $\begin{array}{l}\text { Acute traumatic } \\
\text { pancreatitis }\end{array}$ & $5 \mathrm{~h}$ & $\begin{array}{l}\text { Acupuncture } \\
\text { clinic }\end{array}$ & $\begin{array}{l}\text { Recovered } \\
\quad(4 \mathrm{~d})\end{array}$ \\
\hline Chang 2005 [89] & Korea & $68 / \mathrm{F}$ & LBP & Abdomen & $\begin{array}{l}\text { Aortoduodenal } \\
\text { fistula }\end{array}$ & $2 \mathrm{wk}$ & Not specified & Dead \\
\hline Cheng 2005 [90] & Taiwan & $37 / \mathrm{F}$ & Weight loss & Abdomen & $\begin{array}{l}\text { Rectus sheath } \\
\text { hematoma }\end{array}$ & $4 \mathrm{~h}$ & Not specified & $\begin{array}{l}\text { Recovered } \\
\quad(1 \mathrm{mo})\end{array}$ \\
\hline $\begin{array}{l}\text { Usichenko } 2006 \\
\text { [91] }\end{array}$ & Germany & $78 / \mathrm{M}$ & $\begin{array}{c}\text { Postoperative } \\
\text { pain }\end{array}$ & $\begin{array}{l}\text { Ear lobe } \\
\text { (embedded } \\
\text { needles) }\end{array}$ & Ear hematomas & $4 \mathrm{~d}$ & Not specified & $\begin{array}{c}\text { Recovered } \\
\text { with } \\
\text { discoloration }\end{array}$ \\
\hline Kuo 2010 [92] & Taiwan & $39 / \mathrm{F}$ & $\begin{array}{c}\text { Knee } \\
\text { soreness }\end{array}$ & Popliteal fossa & $\begin{array}{c}\text { Popliteal } \\
\text { arteriovenous } \\
\text { fistula }\end{array}$ & $\begin{array}{l}\text { Several } \\
\text { years }\end{array}$ & Not specified & Discharged \\
\hline
\end{tabular}

TABLE 9: Other complications associated with acupuncture (7 cases).

\begin{tabular}{|c|c|c|c|c|c|c|c|}
\hline $\begin{array}{l}\text { First author /year } \\
\text { (reference) }\end{array}$ & Country & $\begin{array}{c}\text { Case } \\
\text { age/sex }\end{array}$ & Disease treated & Puncture site & Complication & Followup time & Remarks \\
\hline $\begin{array}{l}\text { McCartney } 2000 \\
{[93]}\end{array}$ & UK & $52 / \mathrm{M}$ & LPB & LI4 (Hand) & $\begin{array}{l}\text { Bilateral hand } \\
\text { edema }\end{array}$ & $\begin{array}{l}\text { Recovered } \\
\text { (in } 8 \mathrm{wk} \text { ) }\end{array}$ & $\begin{array}{l}\text { No lab evidence } \\
\text { of inflammation }\end{array}$ \\
\hline $\begin{array}{l}\text { Yanagihara } 2000 \\
{[94]}\end{array}$ & Japan & $55 / \mathrm{F}$ & $\begin{array}{l}\text { Shoulder pain } \\
\text { and lumbago }\end{array}$ & $\begin{array}{l}\text { Back, hip, neck, } \\
\text { legs and arms }\end{array}$ & $\begin{array}{l}\text { Epithelioid } \\
\text { granuloma at } \\
\text { needling sites }\end{array}$ & Improved & $\begin{array}{l}\text { Caused by } \\
\text { silicone coating } \\
\text { on needles }\end{array}$ \\
\hline Kim 2002 [95] & Korea & $37 / \mathrm{F}$ & $\begin{array}{l}\text { Abdominal } \\
\text { discomfort }\end{array}$ & Not state & Pseudolymphoma & Improved & CD-30 positive \\
\hline $\begin{array}{l}\text { Takeishi } 2002 \\
\text { [96] }\end{array}$ & Japan & $66 / \mathrm{F}$ & Arthralgia & Extremities & Localized argyria & Not stated & $\begin{array}{l}\text { Embedded } \\
\text { silver needles } \\
20 \text { y earlier }\end{array}$ \\
\hline Murray 2002 [97] & UK & $35 / \mathrm{M}$ & Tennis elbow & Arm & Pustules & Not stated & $\begin{array}{c}\text { Pt has Behcet } \\
\text { disease }\end{array}$ \\
\hline Vassiou 2003 [98] & Greece & $67 / F$ & LBP & $\begin{array}{l}\text { Chest \& } \\
\text { abdomen }\end{array}$ & Pancytopenia & Not stated & $\begin{array}{l}\text { Embedded } \\
\text { needles } 17 \text { y } \\
\text { earlier }\end{array}$ \\
\hline Pigatto 2004 [99] & Italy & $36 / \mathrm{F}$ & Hyperthyroidism & St10 (neck) & $\begin{array}{l}\text { Scars at needling } \\
\text { site }\end{array}$ & $\begin{array}{c}\text { No } \\
\text { improvement }\end{array}$ & $\begin{array}{l}\text { "Hot needle" } \\
\text { used }\end{array}$ \\
\hline
\end{tabular}

conducted under well-controlled conditions,also found no serious AEs associated with acupuncture [128], although one of these systematic reviews of RCTs separately examined case reports of AEs associated with acupuncture and had findings comparable to ours. However, any medical intervention has the potential to cause damage, particularly when administered by an untrained or unqualified practitioner, or in an unregulated setting. Our objective was thus to identify signals that might suggest the potential for AEs of acupuncture, when administered in specific settings, or when using specific acupuncture styles, and also to compare the patterns of AEs in the past 12 years with the patterns identified in the 35year period covered by our first review. Comparing the new data with that of the previous review shows the emergence of some important new patterns, which may be relevant for future regulation and policy making.

Although the majority of the AEs are still infections, the routes of infection have changed. Our present findings include 239 AEs from infection; 191 occurred in five outbreaks of bacterial infection caused by skin contact with unsterilized equipment and dirty towels, in unhygienic clinical settings. In our previous findings, hepatitis cross-infections from patient to patient due to reused needles (94 cases reported in four outbreaks) were the most frequent source of infection. Since the introduction of disposable needles, hepatitis infections have rarely been reported, which is an important achievement that has resulted from the greater regulation of acupuncture practice, particularly the requirement for disposable needle 
TABLE 10: Adverse reactions associated with acupuncture (10 cases).

\begin{tabular}{|c|c|c|c|c|c|c|}
\hline $\begin{array}{l}\text { First author /year } \\
\text { (reference) }\end{array}$ & Country & $\begin{array}{c}\text { Case } \\
\text { age/sex }\end{array}$ & Disease treated & Puncture sites & Adverse reactions & Remarks \\
\hline $\begin{array}{l}\text { Castro-Durán } \\
2000[105]\end{array}$ & Spain & $48 / \mathrm{F}$ & Arthralgia & Not stated & Pyoderma gangrenosum & Immune response \\
\hline Jenner 2002 [102] & UK & $41 / \mathrm{F}$ & Cancer pain & Points at upper back & Galactorrhoea & Breast cancer \\
\hline Cole 2002 [100] & USA & $25 / \mathrm{M}$ & $\begin{array}{c}\text { Healthy } \\
\text { volunteer for a } \\
\text { clinical study }\end{array}$ & ST36 (bilateral) & Convulsive syncope & Pt was sitting \\
\hline $\begin{array}{l}\text { Campbell } 2005 \\
{[103]}\end{array}$ & UK & $32 / \mathrm{F}$ & Foot pain & Local points at foot & Galactorrhoea (left side) & $\begin{array}{c}\text { Pt had no } \\
\text { lactation prior to } \\
\text { the tx }\end{array}$ \\
\hline \multirow[t]{2}{*}{ Kung 2005 [101] } & Taiwan & $72 / \mathrm{M}$ & Arm pain & LI11, TB5 (arm) & Syncope & Pt was sitting \\
\hline & & $63 / F$ & Ankle pain & GB34, B40 (leg \& ankle) & Syncope & Pt was sitting \\
\hline $\begin{array}{l}\text { Bradbury } 2006 \\
{[104]}\end{array}$ & UK & $50 / \mathrm{F}$ & Shoulder pain & Points around shoulder & Nystagmus & $\begin{array}{l}\text { Semirecumbent } \\
\text { position }\end{array}$ \\
\hline Smyth 2007 [108] & Scotland & $55 / \mathrm{M}$ & Back pain & Back & $\begin{array}{l}\text { Spontaneous needle } \\
\text { movement }\end{array}$ & No complication \\
\hline Hong 2008 [106] & China & $52 / \mathrm{F}$ & Leg weakness & ST36 (leg) & Hepatotoxicity & $\begin{array}{l}\text { Pt was in } \\
\text { menopause }\end{array}$ \\
\hline $\begin{array}{l}\text { Fleming } 2011 \\
{[107]}\end{array}$ & UK & $41 / \mathrm{F}$ & Back pain & Lower back & Eruptive lichen planus & Immune response \\
\hline
\end{tabular}

TABLE 11: Adverse events associated with moxibustion (4 cases).

\begin{tabular}{|c|c|c|c|c|c|c|c|}
\hline $\begin{array}{l}\text { First author /year } \\
\text { (reference) }\end{array}$ & Country & $\begin{array}{c}\text { Case } \\
\text { age/sex }\end{array}$ & Disease treated & Moxibustion site & Adverse events & Practitioner & Remarks \\
\hline $\begin{array}{l}\text { Fisman } \\
2002[109]\end{array}$ & Canada & $38 / \mathrm{M}$ & Not stated & Abdomen & Ecchymoses & Not specified & $\begin{array}{l}\text { Pt had a hx of } \\
\text { liver disease }\end{array}$ \\
\hline Chau 2006 [110] & USA & $53 / \mathrm{F}$ & Headache & Leg and feet & Cellulitis & $\begin{array}{l}\text { Untrained } \\
\text { individual }\end{array}$ & Recovered \\
\hline Lee 2008 [111] & Korea & $78 / \mathrm{F}$ & Pain & Fingers & $\begin{array}{c}\text { Infection caused } \\
\text { spinal epidural } \\
\text { abscess }\end{array}$ & Self & Pt had diabetes \\
\hline Yun 2009 [112] & Korea & $58 / \mathrm{M}$ & $\begin{array}{l}\text { Abdominal } \\
\text { pain }\end{array}$ & Abdomen & $\begin{array}{l}\text { Basal cell } \\
\text { carcinoma }\end{array}$ & Self & $\begin{array}{l}\text { Pt. self-treated } \\
\text { for } 10 \mathrm{y}\end{array}$ \\
\hline
\end{tabular}

use. However, in recent years, bacterial infections, including MRSA and mycobacterium, have become pervasive in healthcare settings in general [129]. Such infections, a pressing concern for all medical practitioners, including acupuncturists, result from poor hygiene. Hygienic clinical settings, sterilized equipment, and clean supplies are critical for preventing future such infections.

Pneumothorax is still the most common organ and tissue injury. There were also cases of spinal cord injuries due to short, small needles embedded laterally along the spine in the Japanese practice known as okibari. The putative mechanism responsible for this $\mathrm{AE}$ is that the imbedded needles used in the Japanese okibari acupuncture technique could spontaneously migrate within the tissue, with some of them migrating to the spinal cord to cause spinal cord injury [130]. However, this AE has significantly decreased since our previous review, in which 11 cases due to this practice were found. In the present review, we found organ injuries mainly to be associated with faulty needle insertion. Heart injuries can be fatal, although no death was reported in the five cases we found. Acupuncture training programs must enhance student knowledge of anatomy at each acupuncture point. Supervised clinical internships must provide rigorous training in needle direction, depth of insertion with attention to the size of the patient, and methods of manipulation.

Three cases reported deaths attributed to acupuncture $[8,60,89]$. Two were due to organ injuries $[60,89]$, and one was due to infection [8]. Of the organ injury deaths, one case from Japan [60] reported that a 72-year-old woman died after bilateral tension pneumothorax following acupuncture. The finding of the autopsy also suggested the patient that may have been injured by the insertion of the needles into the lungs during the previous acupuncture treatments. The second organ injury death, from Korea, reported that a 68year-old woman died of massive hematemesis resulting from aortoduodenal fistula. The autopsy showed an injury to the 
TABLE 12: Adverse events associated with cupping (10 cases).

\begin{tabular}{|c|c|c|c|c|c|c|c|}
\hline $\begin{array}{l}\text { First author /year } \\
\text { (reference) }\end{array}$ & Country & $\begin{array}{c}\text { Case } \\
\text { age/sex }\end{array}$ & Disease treated & Cupping site & Adverse events & Practitioner & Remarks \\
\hline Birol 2005 [113] & Turkey & $36 / \mathrm{F}$ & Cough & Back & Keloid scar & Not specified & $\begin{array}{c}\text { Recovered } \\
\text { (several days) }\end{array}$ \\
\hline Kose 2006 [114] & Turkey & $30 / \mathrm{M}$ & Back pain & Back & $\begin{array}{c}10 \% \text { burns at } \\
\text { shoulder and back }\end{array}$ & Self & Recovered (11 d) \\
\hline Tuncez 2006 [116] & Turkey & $57 / \mathrm{F}$ & LBP & Low Back & Suction bullae & Not stated & $\begin{array}{l}\text { Diabetic; } \\
\text { cupping lasted } \\
40 \mathrm{~min}\end{array}$ \\
\hline Weng 2008 [118] & Taiwan & $58 / \mathrm{F}$ & Not stated & Thigh & $\begin{array}{c}\text { Acquired } \\
\text { hemophilia A }\end{array}$ & Not stated & Improved (1 wk) \\
\hline Sohn 2008 [121] & Korea & $66 / F$ & Pain & Not specified & $\begin{array}{c}\text { Reversible cardiac } \\
\text { hypertrophy }\end{array}$ & Self & $\begin{array}{c}\text { Bloodletting } \\
\text { with cupping } \\
>10 \text { y, recovered } \\
(3 \mathrm{mo})\end{array}$ \\
\hline Lee 2008 [122] & Korea & $39 / \mathrm{M}$ & $\begin{array}{c}\text { Musculoskeletal } \\
\text { pain }\end{array}$ & Back & $\begin{array}{l}\text { Iron deficiency } \\
\text { anemia }\end{array}$ & Not stated & $\begin{array}{c}\text { Bloodletting } \\
\text { with cupping } \mathrm{Pt} \text {. } \\
\text { fully recovered }\end{array}$ \\
\hline Lin 2009 [117] & Taiwan & $55 / \mathrm{M}$ & Not stated & Back & Bullae & Not stated & $\begin{array}{c}\text { Recovered } \\
\text { (several wk) }\end{array}$ \\
\hline Blunt 2010 [119] & UK & $55 / \mathrm{M}$ & Not stated & Back and neck & $\begin{array}{c}\text { Hemorrhagic } \\
\text { stroke (14 h later) }\end{array}$ & Not stated & $\begin{array}{c}\text { May be due to } \\
\text { stimulation of } \\
\text { baroreceptor, } \\
\text { neck area }\end{array}$ \\
\hline Kulahci 2011 [115] & Turkey & $32 / \mathrm{M}$ & Back pain & Back & $\begin{array}{c}\text { Burns on back and } \\
\text { shoulder }\end{array}$ & Mother & Recovered \\
\hline Moon 2011 [120] & Korea & $56 / \mathrm{F}$ & & $\begin{array}{l}\text { Neck and } \\
\text { shoulder }\end{array}$ & $\begin{array}{c}\text { Factitious } \\
\text { panniculitis }\end{array}$ & Self & $\begin{array}{c}\text { Recovered } \\
(3 \mathrm{mo})\end{array}$ \\
\hline
\end{tabular}

abdominal aorta, caused by a deep insertion with a $15 \mathrm{~cm}$ long acupuncture needle into the abdomen [89]. The third case was reported from Scotland in which a 69-year-old man died from an infection after acupuncture treatment at the thigh [8]. The patient was later found to have a preexisting pancytopenia (i.e., low white blood cell count), resulting in an increased susceptibility to infection. The case report author, who is also the practitioner, admitted that the patient's skin at the acupuncture point was not cleaned prior to the needle insertion and later found local muscle infection which led to septicaemia. The patient died a few weeks later from a multiorgan failure. These three unfortunate death cases suggest that biomedical knowledge such as anatomy and microbiology is needed in order avoid organ injury and infection. Skin cleansing should also be required, particularly for those patients with immune compromised condition.

There were only a handful of cases reported by practitioners who performed the acupuncture $[8,100,101,103,104$, 108] including a death report [8]. The rest of the cases were reported by investigators who were not the acupuncturists who performed the treatment. Most cases of AEs did not report the qualification of the practitioner. We would suggest that future report on AEs of acupuncture should include the information on the training qualification of the practitioners and the procedure used for the treatment, such as whether or not clean needle techniques were used.
Acupuncture safety practice guidance or guidelines such as Clean Needle Technique (CNT) appear to have played a critical role in minimizing the number of AEs associated with acupuncture practice [129]. In the United States, CNT was first addressed by the National Certification Commission for Acupuncture and Oriental Medicine in 1984. This course is designed to train professional acupuncturists on safe practice procedures. Course content includes training on microbiology, infection control, skills of adequately setting up a sterile practice area (e.g., adequate use of disinfectant and sterile equipment), adequate needle insertion, and adequate handling of AEs associated with acupuncture [130]. CNT courses are now offered by the US Council of Colleges of Acupuncture and Oriental Medicine and required by the acupuncture licensing boards of each state; as a result, reported acupuncture AE incidents have significantly decreased in the United States. In our previous review, about half of the 202 cases of AE that we identified were from the USA. However, as our present review shows, AE cases reported from the USA are now rare. Of the 308 cases we found, only 13 were from the United States, and out of 239 cases of infection, only 5 are from the United States. It should be noted that there were very few case reports of AEs from China included in this review, although acupuncture is widely practiced in China. We are aware that cases of AEs associated with acupuncture performed in China are likely to be reported in Chinese 
language case reports, which are not reflected in the present review due to language limitation. We are currently preparing a separate review on AEs reported in China.

In conclusion, although serious AEs associated with acupuncture are rare, acupuncture practice is not risk-free. Adequate regulation can even further minimize any risk. We recommend that not only adequate training in biomedical knowledge, such as anatomy and microbiology, but also safe and clean practice guidelines are necessary requirements and should continue to be enforced in countries such as the United States where they exist, and that countries without such guidelines should consider developing them in order to minimize acupuncture AEs.

\section{Acknowledgments}

This work was supported partially by Grant no. R24 AT001293-04 from the National Center for Complementary and Alternative Medicine (NCCAM) at the US National Institutes of Health-grant awarded to the University of Maryland School of Medicine, Baltimore, Maryland. This paper's contents are solely the responsibility of the author and do not necessarily represent the official views of NCCAM. The authors would also like to thank Dr. Lyn Lowry for her editorial assistance.

\section{References}

[1] X. Cheng, Chinese Acupuncture and Moxibustion, Foreign Languages Press, Beijing, China, 3rd edition, 2010.

[2] P. M. Barnes, B. Bloom, and R. L. Nahin, "Complementary and alternative medicine use among adults and children: United States, 2007," National Health Statistics Reports, no. 12, pp. 1-23, 2009.

[3] H. MacPherson, K. Thomas, S. Walters, and M. Fitter, “The York acupuncture safety study: prospective survey of 34,000 treatments by traditional acupuncturists," British Medical Journal, vol. 323, no. 7311, pp. 486-487, 2001.

[4] D. Melchart, W. Weidenhammer, A. Streng et al., "Prospective investigation of adverse effects of acupuncture in 97733 Patients," Archives of Internal Medicine, vol. 164, no. 1, pp. 104105, 2004.

[5] L. Lao, G. R. Hamilton, J. Fu, and B. M. Berman, "Is acupuncture safe? A systematic review of case reports," Alternative Therapies in Health and Medicine, vol. 9, no. 1, pp. 72-83, 2003.

[6] V. Wiwanitkit, "HIV infection after Chinese traditional acupuncture treatment," Complementary Therapies in Medicine, vol. 11, no. 4, p. 272, 2003.

[7] J. K. Kim, T. Y. Kim, D. H. Kim, and M. S. Yoon, "Three cases of primary inoculation tuberculosis as a result of illegal acupuncture," Annals of Dermatology, vol. 22, no. 3, pp. 341-345, 2010.

[8] R. Simmons, "Acupuncture with significant infection, in a 'well' patient," Acupuncture in Medicine, vol. 24, no. 1, p. 37, 2006.

[9] N. Origuchi, T. Komiyama, K. Ohyama, T. Wakabayashi, and H. Shigematsu, "Infectious aneurysm formation after depot acupuncture," European Journal of Vascular and Endovascular Surgery, vol. 20, no. 2, pp. 211-213, 2000.

[10] M. Ishibe, M. Inoue, and K. Saitou, "Septic arthritis of a lumbar facet joint due to pyonex," Archives of Orthopaedic and Trauma Surgery, vol. 121, no. 1-2, pp. 90-92, 2001.
[11] P. C. Woo, J. H. Li, W. Tang, and K. Yuen, "Acupuncture mycobacteriosis," The New England Journal of Medicine, vol. 345, no. 11, pp. 842-843, 2001.

[12] P. Nambiar and C. Ratnatunga, "Prosthetic valve endocarditis in a patient with Marfan's syndrome following acupuncture," Journal of Heart Valve Disease, vol. 10, no. 5, pp. 689-690, 2001.

[13] N. Shah, C. Hing, K. Tucker, and R. Crawford, "Infected compartment syndrome after acupuncture," Acupuncture in Medicine, vol. 20, no. 2-3, pp. 105-106, 2002.

[14] B. R. Leavy, "Apparent adverse outcome of acupuncture," Journal of the American Board of Family Practice, vol. 15, no. 3, pp. 246-248, 2002.

[15] A. J. Laing, H. Mullett, and M. F. X. Gilmore, "Acupunctureassociated arthritis in a joint with an orthopaedic implant," Journal of Infection, vol. 44, no. 1, pp. 43-44, 2002.

[16] K. Uchino, Y. Mochida, T. Ebina et al., "Infected left atrial myxoma," Internal Medicine, vol. 41, no. 11, pp. 957-960, 2002.

[17] P. C. Y. Woo, S. K. P. Lau, S. S. Y. Wong, and K. Y. Yuen, “Staphylococcus aureus subcutaneous abscess complicating acupuncture: need for implementation of proper infection control guidelines," New Microbiologica, vol. 26, no. 2, pp. 169-174, 2003.

[18] M. Ara, C. Sáenz de Santamaría, P. Zaballos, C. Yus, and M. A. Lezcano, "Mycobacterium chelonae infection with multiple cutaneous lesions after treatment with acupuncture," International Journal of Dermatology, vol. 42, no. 8, pp. 642-644, 2003.

[19] Y. P. Cho, H. J. Jang, J. S. Kim, Y. H. Kim, M. S. Han, and S. G. Lee, "Retroperitoneal abscess complicated by acupuncture: case report," Journal of Korean Medical Science, vol. 18, no. 5, pp. 756757, 2003.

[20] A. Kettaneh, N. Ozan, J. Stirnemann, O. Fain, and M. Thomas, "Facial erysipelas after receiving acupuncture treatment," Scandinavian Journal of Infectious Diseases, vol. 35, no. 11-12, pp. 911912, 2003.

[21] K. Y. Ha and Y. H. Kim, "Chronic inflammatory granuloma mimics clinical manifestations of lumbar spinal stenosis after acupuncture: a case report," Spine, vol. 28, no. 11, pp. E217-E220, 2003.

[22] F. Lin and P. Choong, "Soft tissue abscess and osteomyelitis secondary to acupuncture," ANZ Journal of Surgery, vol. 73, no. 9, p. 770, 2003.

[23] S. Daivajna, A. Jones, M. O’Malley, and H. Mehdian, "Unilateral septic arthritis of a lumbar facet joint secondary to acupuncture treatment-a case report," Acupuncture in Medicine, vol. 22, no. 3, pp. 152-155, 2004.

[24] R. C. Studd and P. J. Stewart, "Images in clinical medicine. Intraabdominal abscess after acupuncture," The New England Journal of Medicine, vol. 350, no. 17, p. 1763, 2004.

[25] P. S. Kim and W. Hsu, "Discitis in an adult following acupuncture treatment: a case report," The Journal of the Canadian Chiropractic Association, vol. 48, no. 2, pp. 132-136, 2004.

[26] A. Saw, M. K. Kwan, and S. Sengupta, "Necrotising fasciitis: a life-threatening complication of acupuncture in a patient with diabetes mellitus," Singapore Medical Journal, vol. 45, no. 4, pp. 180-182, 2004.

[27] M. H. Chen, M. H. Chen, and J. S. Huang, "Cervical subdural empyema following acupuncture," Journal of Clinical Neuroscience, vol. 11, no. 8, pp. 909-911, 2004.

[28] Z. Vucicevic, M. Sharma, S. Miklic, and Z. Ferencic, "Multiloculated pleural empyema following acupuncture," Infection, vol. 33, no. 4, pp. 297-298, 2005. 
[29] M. S. Bang and S. H. Lim, "Paraplegia caused by spinal infection after acupuncture," Spinal Cord, vol. 44, no. 4, pp. 258-259, 2006.

[30] E. J. Seeley and H. F. Chambers, "Diabetic ketoacidosis precipitated by Staphylococcus aureus abscess and bacteremia due to acupuncture: case report and review of the literature," Clinical Infectious Diseases, vol. 43, no. 1, pp. e6-e8, 2006.

[31] C. H. Tien, G. S. Huang, C. C. Chang, D. M. Chang, and J. H. Lai, "Acupuncture-associated listeria monocytogenes arthritis in a patient with rheumatoid arthritis," Joint Bone Spine, vol. 75, no. 4, pp. 502-503, 2008.

[32] A. E. Morgan, "Pseudomonas aeruginosa infection due to acupunctural ear stapling," American Journal of Infection Control, vol. 36, no. 8, p. 602, 2008.

[33] S. Lee, S. H. Lim, D. K. Kim, and H. C. Joo, "Acupuncture induced necrotizing aortitis with infected pseudoaneurysm formation," Yonsei Medical Journal, vol. 49, no. 2, pp. 322-324, 2008.

[34] J. K. Hwang, J. Kim, B. J. Lee, J. J. Park, J. S. Kim, and Y. T. Bak, "Pneumoretroperitoneum following acupuncture," Journal of Alternative and Complementary Medicine, vol. 14, no. 10, pp. 1299-1301, 2008.

[35] K. H. Jeong and M. H. Lee, "Two cases of factitial panniculitis induced by electroacupuncture," Clinical and Experimental Dermatology, vol. 34, no. 5, pp. el70-e173, 2009.

[36] J. K. Hwang, J. Kim, B. J. Lee, J. J. Park, J. S. Kim, and Y. T. Bak, "Pneumoretroperitoneum following acupuncture," Journal of Alternative and Complementary Medicine, vol. 14, no. 10, pp. 1299-1301, 2008.

[37] C. T. Wu, J. L. Huang, S. H. Hsia, H. Y. Lee, and J. J. Lin, "Pott's puffy tumor after acupuncture therapy," European Journal of Pediatrics, vol. 168, no. 9, pp. 1147-1149, 2009.

[38] P. C. Y. Woo, S. K. P. Lau, and K. Y. Yuen, "First report of methicillin-resistant Staphylococcus aureus septic arthritis complicating acupuncture: simple procedure resulting in most devastating outcome," Diagnostic Microbiology and Infectious Disease, vol. 63, no. 1, pp. 92-95, 2009.

[39] M. Ogasawara, K. Oda, K. Yamaji, and Y. Takasaki, "Polyarticular septic arthritis with bilateral psoas abscesses following acupuncture," Acupuncture in Medicine, vol. 27, no. 2, pp. 81-82, 2009.

[40] A. Guevara-Patiño, M. Sandoval de Mora, A. Farreras, I. RiveraOlivero, D. Fermin, and J. H. de Waard, "Soft tissue infection due to Mycobacterium fortuitum following acupuncture: a case report and review of the literature," Journal of Infection in Developing Countries, vol. 4, no. 8, pp. 521-525, 2010.

[41] A. Nakajima, R. Kaneyama, H. Watanabe et al., "Acupuncture needle-associated prosthetic knee infection after total knee arthroplasty," Modern Rheumatology, vol. 20, no. 6, pp. 627-631, 2010.

[42] L. K. Winter and J. H. Spiegel, "Ear stapling: a risky and unproven procedure for appetite suppression and weight loss," Ear, Nose and Throat Journal, vol. 89, no. 1, pp. E20-E22, 2010.

[43] J. W. Kim and Y. S. Kim, "Psoas abscess formation after acupuncture in a hemodialysis patient," Hemodialysis International, vol. 14, no. 3, pp. 343-344, 2010.

[44] H. J. Cho, D. Y. Lee, J. H. Lee, J. M. Yang, and E. S. Lee, "A case of Mycobacterium abscessus skin infection caused by multiple acupunctures," Clinical and Experimental Dermatology, vol. 35, no. 4, pp. 444-445, 2010.
[45] F. Macuha Jr., A. Ahn, and R. Graham, "Necrotizing fasciitis associated with acupuncture: a case report," Journal of Hospital Medicine, vol. 5, no. 9, pp. 565-566, 2010.

[46] D. A. Buckley, "Staphylococcus aureus endocarditis as a complication of acupuncture for eczema," British Journal of Dermatology, vol. 164, no. 6, pp. 1405-1406, 2011.

[47] C. M. Kuo, C. K. Wu, and W. C. Lien, "Bilateral psoas abscess formation after acupuncture," Journal of Emergency Medicine, vol. 40, no. 2, pp. 215-216, 2011.

[48] A. N. Castro-Silva, A. O. Freire, R. S. Grinbaum et al., "Cutaneous Mycobacterium haemophilum infection in a kidney transplant recipient after acupuncture treatment," Transplant Infectious Disease, vol. 13, no. 1, pp. 33-37, 2011.

[49] R. L. Hsieh, C. H. Huang, and W. C. Uen, "Necrotizing fasciitis after acupuncture in a patient with aplastic anemia," The Journal of Alternative and Complementary Medicine, vol. 17, no. 9, pp. 871-874, 2011.

[50] P. C. Y. Woo, K. W. Leung, S. S. Y. Wong, K. T. K. Chong, E. Y. L. Cheung, and K. Y. Yuen, "Relatively alcohol-resistant mycobacteria are emerging pathogens in patients receiving acupuncture treatment," Journal of Clinical Microbiology, vol. 40, no. 4, pp. 1219-1224, 2002.

[51] P. Tang, S. Walsh, C. Murray et al., "Outbreak of acupunctureassociated cutaneous Mycobacterium abscessus infections," Journal of Cutaneous Medicine and Surgery, vol. 10, no. 4, pp. 166169, 2006.

[52] J. Y. Song, J. W. Sohn, H. W. Jeong, H. J. Cheong, W. J. Kim, and M. J. Kim, "An outbreak of post-acupuncture cutaneous infection due to Mycobacterium abscessus," BMC Infectious Diseases, vol. 6, article 6, 2006.

[53] R. J. Murray, J. C. Pearson, G. W. Coombs et al., "Outbreak of invasive methicillin-resistant Staphylococcus aureus infection associated with acupuncture and joint injection," Infection Control and Hospital Epidemiology, vol. 29, no. 9, pp. 859-865, 2008.

[54] S. J. Koh, T. Song, Y. A. Kang et al., "An outbreak of skin and soft tissue infection caused by Mycobacterium abscessus following acupuncture," Clinical Microbiology and Infection, vol. 16, no. 7, pp. 895-901, 2010.

[55] J. T. Liou, F. C. Liu, S. T. Hsin, D. C. W. Sum, and P. W. Lui, "Broken needle in the cervical spine: a previously unreported complication of Xiaozendao acupuncture therapy," Journal of Alternative and Complementary Medicine, vol. 13, no. 1, pp. 129132, 2007.

[56] J. H. Heo, M. H. Bae, and S. J. Lee, "Intracranial hemorrhage and cerebellar infarction caused by acupuncture," Neurology India, vol. 59, no. 2, pp. 303-304, 2011.

[57] J. H. Kim, S. H. Kim, Y. J. Lee, J. S. Hong, R. Ahn, and E. S. Hong, "Hemopericardium following acupuncture," Yonsei Medical Journal, vol. 52, no. 1, pp. 207-209, 2011.

[58] C. L. Kao and J. P. Chang, "Bilateral pneumothorax after acupuncture," Journal of Emergency Medicine, vol. 22, no. 1, pp. 101$102,2002$.

[59] J. S. Leung, "Complementary medicine, acupuncture, and pneumothorax," Hong Kong Medical Journal, vol. 8, no. 3, pp. 225226, 2002.

[60] K. Iwadate, H. Ito, S. Katsumura et al., "An autopsy case of bilateral tension pneumothorax after acupuncture," Legal Medicine, vol. 5, no. 3, pp. 170-174, 2003.

[61] E. Peuker, "Case report of tension pneumothorax related to acupuncture," Acupuncture in Medicine, vol. 22, no. 1, pp. 4043, 2004. 
[62] K. Saifeldeen and M. Evans, "Acupuncture associated pneumothorax," Emergency Medicine Journal, vol. 21, no. 3, p. 398, 2004.

[63] W. M. Lee, H. B. Leung, and W. C. Wong, "Iatrogenic bilateral pneumothorax arising from acupuncture: a case report," Journal of Orthopaedic Surgery, vol. 13, no. 3, pp. 300-302, 2005.

[64] R. J. Chauffe and A. L. Duskin, "Pneumothorax secondary to acupuncture therapy," Southern Medical Journal, vol. 99, no. 11, pp. 1297-1299, 2006.

[65] J. W. Su, C. H. Lim, and Y. L. Chua, "Bilateral pneumothoraces as a complication of acupuncture," Singapore Medical Journal, vol. 48, no. 1, pp. e32-e33, 2007.

[66] W. B. Von Riedenauer, M. K. Baker, and R. J. Brewer, "Videoassisted thorascopic removal of migratory acupuncture needle causing pneumothorax," Chest, vol. 131, no. 3, pp. 899-901, 2007.

[67] J. K. Juss, C. A. Speed, J. Warrington, and R. Mahadeva, "Acupuncture induced pneumothorax-a case report," Acupuncture in Medicine, vol. 26, no. 3, pp. 193-196, 2008.

[68] J. C. Richter, W. Kamali, and P. O'Connor, "Pneumothorax and pleural empyema after acupuncture," Internal Medicine Journal, vol. 38, no. 8, pp. 678-680, 2008.

[69] B. Kennedy and L. Beckert, "A case of acupuncture-induced pneumothorax," New Zealand Medical Journal, vol. 123, no. 1320, pp. 88-90, 2010.

[70] M. Inayama, T. Shinohara, H. Hino, M. Yoshida, and F. Ogushi, "Chylothorax caused by acupuncture," Internal Medicine, vol. 50, no. 20, pp. 2375-2377, 2011.

[71] D. C. A. Choo and G. Yue, "Acute intracranial hemorrhage caused by acupuncture," Headache, vol. 40, no. 5, pp. 397-398, 2000.

[72] Y. Hama and T. Kaji, "A migrated acupuncture needle in the medulla oblongata," Archives of Neurology, vol. 61, no. 10, p. 1608, 2004.

[73] B. Eftekhar, E. Ketabchi, M. Ghodsi, and B. Esmaeeli, "Lumbar epidural hematoma due to lumbar acupunctures," Neurology India, vol. 53, no. 2, pp. 245-246, 2005.

[74] J. C. Chen, Y. Chen, S. M. Lin, H. J. Yang, C. F. Su, and S. H. Tseng, "Acute spinal epidural hematoma after acupuncture," Journal of Trauma, vol. 60, no. 2, pp. 414-416, 2006.

[75] J. E. Ulloth and S. J. Haines, "Acupuncture needles causing lumbar cerebrospinal fluid fistula. Case report," Journal of Neurosurgery, vol. 6, no. 6, pp. 567-569, 2007.

[76] Y. Tsukazaki, T. Inagaki, Y. Yamanouchi, K. Kawamoto, and N. Oka, "Traumatic subarachnoid hemorrhage associated with acupuncture," Headache, vol. 48, no. 8, pp. 1240-1241, 2008.

[77] J. H. Lee, H. Lee, and D. J. Jo, "An acute cervical epidural hematoma as a complication of dry needling," Spine, vol. 36, no. 13, pp. E891-E893, 2011.

[78] M. Sato, H. Katsumoto, K. Kawamura, H. Sugiyama, and T. Takahashi, "Peroneal nerve palsy following acupuncture treatment: a case report," The Journal of Bone \& Joint Surgery A, vol. 85, no. 5, pp. 916-918, 2003.

[79] B. S. Patrick, "Acupuncture complication-a case report," Journal of the Mississippi State Medical Association, vol. 46, no. 7, pp. 195-197, 2005.

[80] P. Rosted and D. R. Woolley, "Bell's Palsy following acupuncture treatment-a case report," Acupuncture in Medicine, vol. 25, no. 1-2, pp. 47-48, 2007.

[81] C. H. Lee, J. K. Hyun, and S. J. Lee, "Isolated median sensory neuropathy after acupuncture," Archives of Physical Medicine and Rehabilitation, vol. 89, no. 12, pp. 2379-2381, 2008.
[82] A. Kirchgatterer, C. D. Schwarz, E. Höller, C. Punzengruber, P. Hartl, and B. Eber, "Cardiac tamponade following acupuncture," Chest, vol. 117, no. 5, pp. 1510-1511, 2000.

[83] J. H. Park, H. J. Shin, S. J. Choo, J. K. Song, and J. J. Kim, "Successful removal of migrated acupuncture needles in a patient with cardiac tamponade by means of intraoperative transesophageal echocardiographic assistance," The Journal of Thoracic and Cardiovascular Surgery, vol. 130, no. 1, pp. 210-212, 2005.

[84] Y. J. Kim, J. Y. Kim, B. W. Choi, J. E. Nam, T. H. Kim, and K. O. Choe, "Images in cardiovascular medicine. Right ventricular acupuncture needle embolism detected on coronary computed tomography angiography," Circulation, vol. 114, no. 23, pp. e623e626, 2006.

[85] B. G. Song and J. R. Park, "Acupuncture needles over the myocardium," Heart Lung and Circulation, vol. 19, no. 8, p. 480, 2010.

[86] D. I. Kim, S. H. Huh, B. B. Lee, D. K. Kim, and Y. S. Do, "Pseudoaneurysm of the abdominal aorta caused by acupuncture therapy," Surgery Today, vol. 32, no. 10, pp. 942-943, 2002.

[87] C. L. Kao and J. P. Chang, "Pseudoaneurysm of the popliteal artery: a rare sequela of acupuncture," Texas Heart Institute Journal, vol. 29, no. 2, pp. 126-129, 2002.

[88] M. S. Uhm, Y. S. Kim, S. C. Suh et al., "Acute pancreatitis induced by traditional acupuncture therapy," European Journal of Gastroenterology and Hepatology, vol. 17, no. 6, pp. 675-677, 2005.

[89] S. A. Chang, Y. J. Kim, D. W. Sohn, Y. B. Park, and Y. S. Choi, "Aortoduodenal fistula complicated by acupuncture," International Journal of Cardiology, vol. 104, no. 2, pp. 241-242, 2005.

[90] S. P. Cheng and C. L. Liu, "Rectus sheath hematoma after acupuncture," Journal of Emergency Medicine, vol. 29, no. 1, pp. 101-102, 2005.

[91] T. I. Usichenko, M. Dinse, D. Pavlovic, and C. Lehmann, "Hemorrhage after auricular acupuncture due to postoperative dilutional thrombocytopenia," Anesthesia and Analgesia, vol. 103, no. 5, pp. 1333-1334, 2006.

[92] H. F. Kuo, M. C. Paul Shih, W. P. Kao et al., "Acupunctureinduced popliteal arteriovenous fistula successfully treated with percutaneous endovascular intervention," Kaohsiung Journal of Medical Sciences, vol. 26, no. 3, pp. 158-162, 2010.

[93] C. J. L. McCartney, R. Herriot, and W. A. Chambers, "Bilateral hand oedema related to acupuncture," Pain, vol. 84, no. 2-3, pp. 429-430, 2000.

[94] M. Yanagihara, T. Fujii, N. Wakamatu, H. Ishizaki, T. Takehara, and K. Nawate, "Silicone granuloma on the entry points of acupuncture, venepuncture and surgical needles," Journal of Cutaneous Pathology, vol. 27, no. 6, pp. 301-305, 2000.

[95] K. J. Kim, M. W. Lee, J. H. Choi, K. J. Sung, K. C. Moon, and J. K. Koh, "CD30-positive T-cell-rich pseudolymphoma induced by gold acupuncture," British Journal of Dermatology, vol. 146, no. 5, pp. 882-884, 2002.

[96] E. Takeishi, R. Hirose, Y. Hamasaki, and I. Katayama, "Localized argyria 20-years after embedding of acupuncture needles," European Journal of Dermatology, vol. 12, no. 6, pp. 609611, 2002.

[97] P. I. Murray and N. Aboteen, "Complication of acupuncture in a patient with Behçet's disease," British Journal of Ophthalmology, vol. 86, no. 4, pp. 476-477, 2002.

[98] K. Vassiou, N. L. Kelekis, and I. V. Fezoulidis, "Multiple retained acupuncture needle fragments," European Radiology, vol. 13, no. 5, pp. 1188-1189, 2003. 
[99] P. D. Pigatto and G. Guzzi, "Acupuncture needle scars," British Journal of Dermatology, vol. 150, no. 2, p. 364, 2004.

[100] M. Cole, J. Shen, and D. Hommer, "Convulsive syncope associated with acupuncture," American Journal of the Medical Sciences, vol. 324, no. 5, pp. 288-289, 2002.

[101] Y. Y. Kung, F. P. Chen, S. J. Hwang, J. C. Hsieh, and Y. Y. Lin, "Convulsive syncope: an unusual complication of acupuncture treatment in older patients," Journal of Alternative and Complementary Medicine, vol. 11, no. 3, pp. 535-537, 2005.

[102] C. Jenner and J. Filshie, "Galactorrhoea following acupuncture," Acupuncture in Medicine, vol. 20, no. 2-3, pp. 107-108, 2002.

[103] A. Campbell and J. Macglashan, "Acupuncture-induced galactorrhoea-a case report," Acupuncture in Medicine, vol. 23, no. 3, p. 146, 2005.

[104] A. Bradbury, J. Botancor, and A. White, "Nystagmus following acupuncture-a case report," Acupuncture in Medicine, vol. 24, no. 1, pp. 33-34, 2006.

[105] J. Castro-Durán, M. Martín-Armada, and J. Jiménez-Alonso, "Pyoderma gangrenosum induced by acupuncture in a patient with ulcerative colitis," Archives of Internal Medicine, vol. 160, no. 15, p. 2394, 2000.

[106] L. Hong, Z. Chen, X. Zhou et al., "Acupuncture may cause hepatotoxicity in patients in climacteric," Climacteric, vol. 11, no. 4, pp. 345-346, 2008.

[107] J. Fleming, S. Diaz-Cano, and E. Higgins, "Eruptive lichen planus triggered by acupuncture," Archives of Dermatology, vol. 147, no. 3, pp. 361-362, 2011.

[108] M. J. Smyth, "Spontaneous post-insertion needle movementan unusual risk in acupuncture treatment," Acupuncture in Medicine, vol. 25, no. 1-2, p. 49, 2007.

[109] D. Fisman, "Unusual skin findings in a patient with liver disease," Canadian Medical Association Journal, vol. 166, no. 12, p. 1567, 2002.

[110] N. Chau, "Moxibustion burns," Journal of Hospital Medicine, vol. 1, no. 6, p. 367, 2006.

[111] K. W. Lee, S. J. Han, D. J. Kim, and M. Lee, "Spinal epidural abscess associated with moxibustion-related infection of the finger," The Journal of Spinal Cord Medicine, vol. 31, no. 3, pp. 319-323, 2008.

[112] S. K. Yun, S. M. Kim, J. Park et al., "Large superficial basal cell carcinoma arising from moxa cautery," European Journal of Dermatology, vol. 19, no. 4, pp. 387-388, 2009.

[113] A. Birol, E. Erkek, G. S. Kurtipek, and M. Kocak, "Keloid secondary to therapeutic cupping: an unusual complication," Journal of the European Academy of Dermatology and Venereology, vol. 19, no. 4, p. 507, 2005.

[114] A. A. Kose, Y. Karabağli, and C. Cetin, "An unusual cause of burns due to cupping: complication of a folk medicine remedy," Burns, vol. 32, no. 1, pp. 126-127, 2006.

[115] Y. Kulahci, C. Sever, C. Sahin, and R. Evinc, "Burn caused by cupping therapy," Journal of Burn Care and Research, vol. 32, no. 2, p. e31, 2011.

[116] F. Tuncez, Y. Bagci, G. S. Kurtipek, and E. Erkek, "Suction bullae as a complication of prolonged cupping," Clinical and Experimental Dermatology, vol. 31, no. 2, pp. 300-301, 2006.

[117] C. W. Lin, J. T. J. Wang, C. S. Choy, and H. H. Tung, "Iatrogenic bullae following cupping therapy," Journal of Alternative and Complementary Medicine, vol. 15, no. 11, pp. 1243-1245, 2009.

[118] Y. M. Weng and C. T. Hsiao, "Acquired hemophilia A associated with therapeutic cupping," American Journal of Emergency Medicine, vol. 26, no. 8, pp. 970.e1-970.e2, 2008.
[119] S. B. Blunt and H. P. Lee, "Can traditional "cupping" treatment cause a stroke?” Medical Hypotheses, vol. 74, no. 5, pp. 945-949, 2010.

[120] S. H. Moon, H. H. Han, and J. W. Rhie, "Factitious panniculitis induced by cupping therapy," Journal of Craniofacial Surgery, vol. 22, no. 6, pp. 2412-2414, 2011.

[121] I. S. Sohn, E. S. Jin, J. M. Cho et al., "Bloodletting-induced cardiomyopathy: reversible cardiac hypertrophy in severe chronic anaemia from long-term bloodletting with cupping," European Journal of Echocardiography, vol. 9, no. 5, pp. 585-586, 2008.

[122] H. J. Lee, N. H. Park, H. J. Yun, S. Kim, and D. Y. Jo, "Cupping therapy-induced iron deficiency anemia in a healthy man," American Journal of Medicine, vol. 121, no. 8, pp. e5-e6, 2008.

[123] C. M. Witt, D. Pach, B. Brinkhaus et al., "Safety of acupuncture: results of a prospective observational study with 229,230 patients and introduction of a medical information and consent form," Forschende Komplementarmedizin, vol. 16, no. 2, pp. 9197, 2009.

[124] A. White, S. Hayhoe, A. Hart, and E. Ernst, "Adverse events following acupuncture: prospective survey of 32000 consultations with doctors and physiotherapists," British Medical Journal, vol. 323, no. 7311, pp. 485-486, 2001.

[125] C. M. Witt, L. Lao, and H. Macpherson, "Evidence on acupuncture safety needs to be based on large-scale prospective surveys, not single case reports," Pain, vol. 152, no. 9, p. 2180, 2011.

[126] E. Manheimer, K. Cheng, K. Linde et al., "Acupuncture for peripheral joint osteoarthritis," Cochrane Database of Systematic Reviews, no. 1, Article ID CD001977, 2010.

[127] E. Manheimer, K. Cheng, L. S. Wieland et al., "Acupuncture for treatment of irritable bowel syndrome," Cochrane Database of Systematic Reviews, no. 5, Article ID CD005111, 2012.

[128] E. Ernst, M. S. Lee, and T. Y. Choi, "Acupuncture: does it alleviate pain and are there serious risks? A review of reviews," Pain, vol. 152, no. 4, pp. 755-764, 2011.

[129] W. H. Lim, R. Lien, Y. C. Huang, W. J. Lee, and J. Y. Lai, "Community-associated methicillin-resistant Staphylococcus aureus necrotizing pneumonia in a healthy neonate," Journal of Microbiology, Immunology and Infection, 2012.

[130] Clean Needle Technique Manual for Acupuncturists, NAF Publications, 6th edition, 2009. 


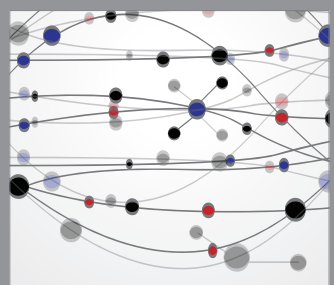

The Scientific World Journal
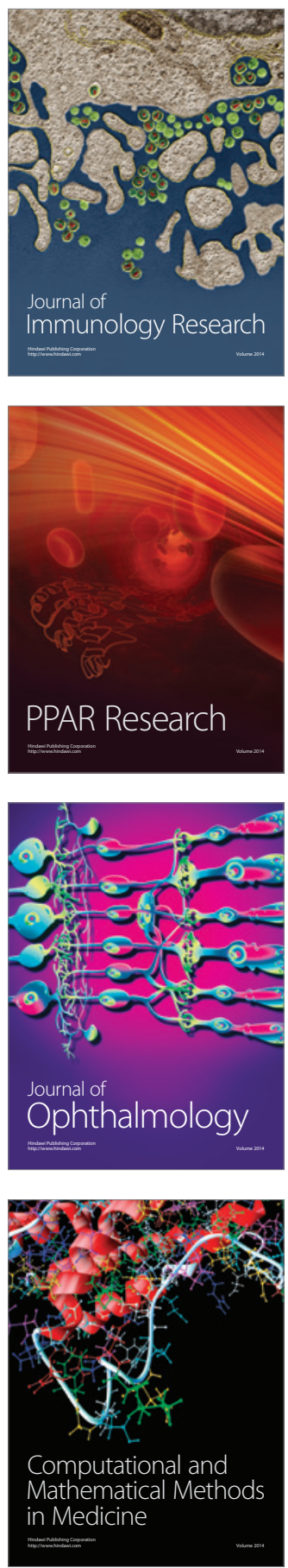

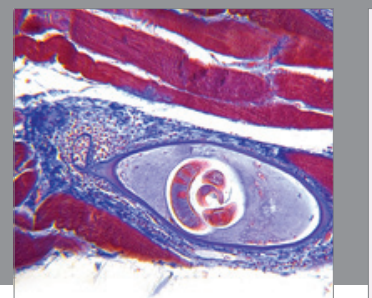

Gastroenterology

Research and Practice
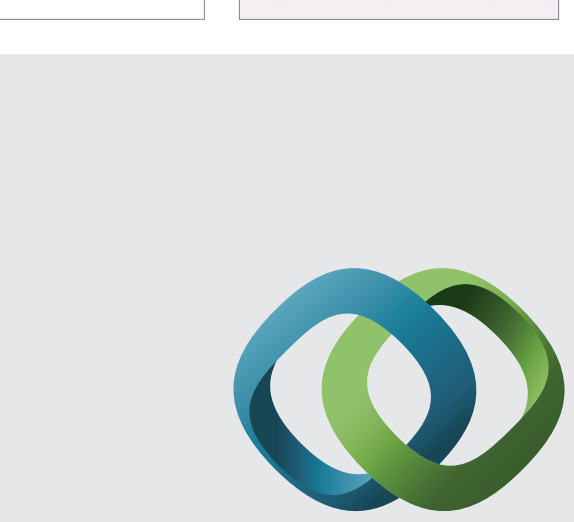

\section{Hindawi}

Submit your manuscripts at

http://www.hindawi.com
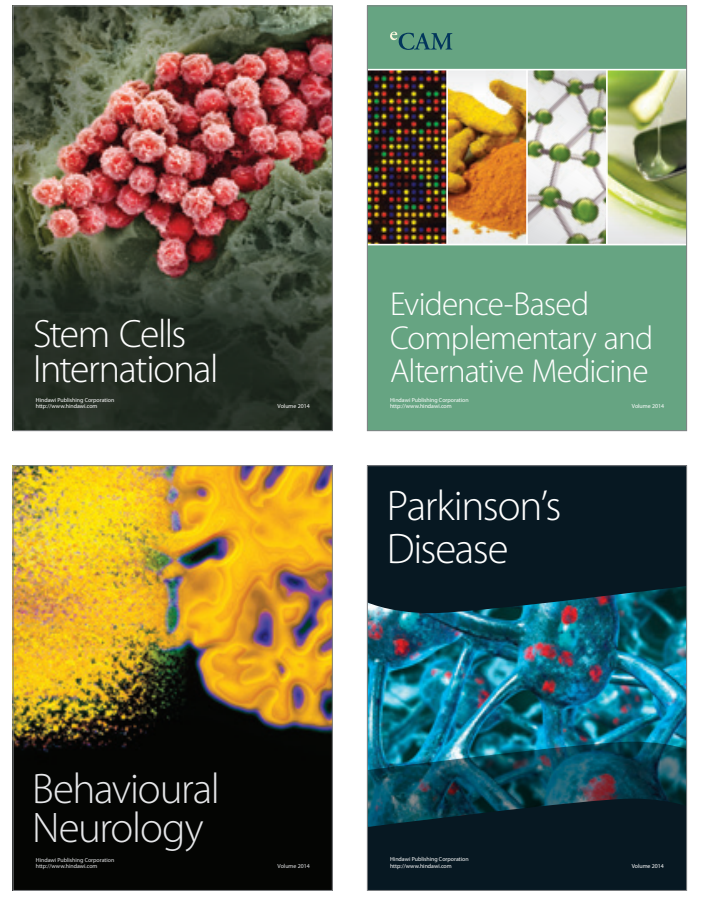
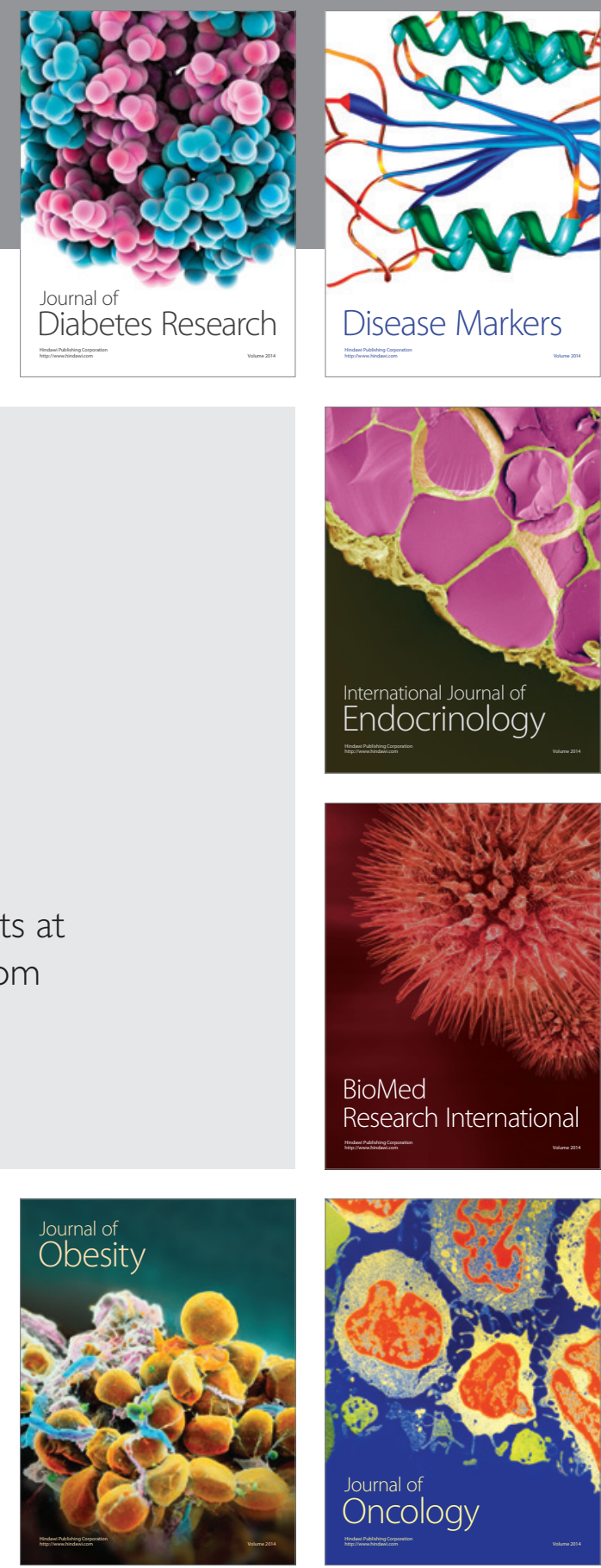

Disease Markers
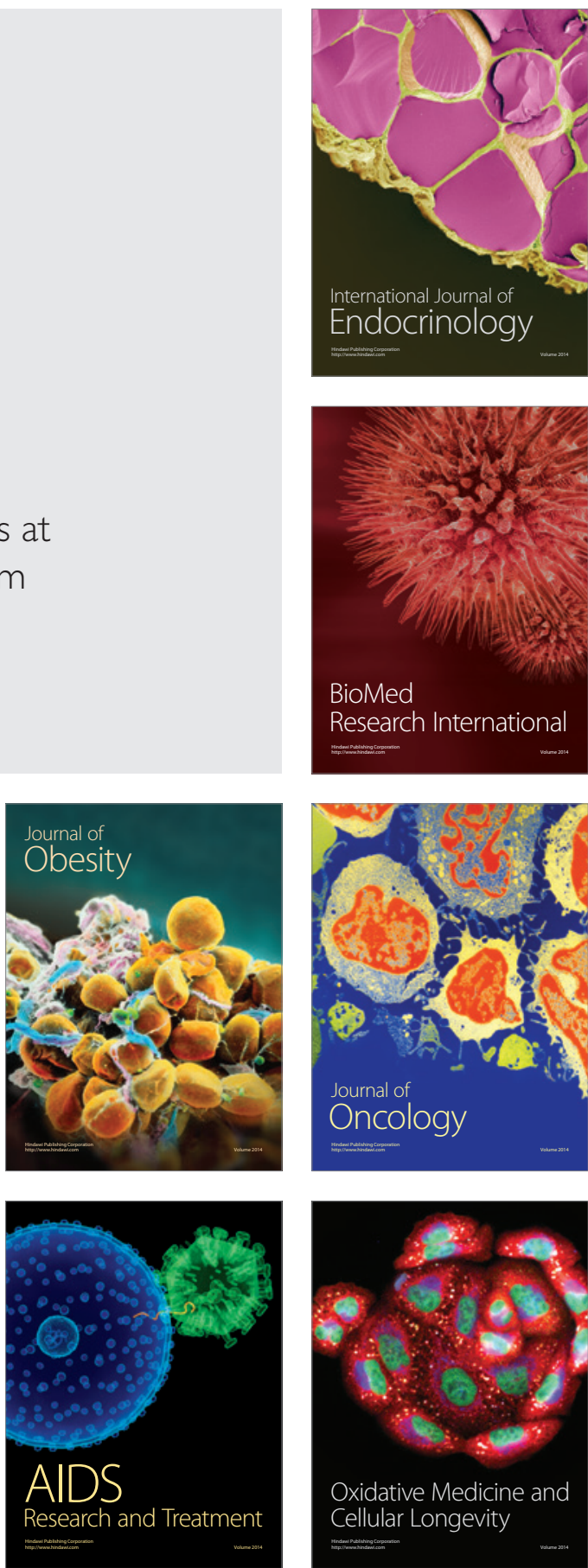